\title{
Bluetooth Controlled Hexapod Robot Design
}

\author{
Koray Kavlak $^{1 *}$, İbrahim Ali Kartal ${ }^{2}$ \\ 1* Konya Technical University, Faculty of Engineering and Natural Sciences, Department of Mechanical Engineering, Konya, Turkey, (ORCID: 0000-0001-9272- \\ 6754),kkavlak@ktun.edu.tr \\ ${ }^{2}$ Konya Technical University, Faculty of Engineering and Natural Sciences, Department of Mechanical Engineering, Konya, Turkey, (ORCID: 0000-0002-4901-5663), \\ ibrahimalikartal@gmail.com
}

(3rd International Congress on Human-Computer Interaction, Optimization and Robotic Applications June 11-13, 2021)

(DOI: $10.31590 /$ ejosat.960612)

ATIF/REFERENCE: Kavlak, K. \& Kartal, İ. A. (2021). Bluetooth Controlled Hexapod Robot Design. European Journal of Science and Technology, (26), 421-424.

\begin{abstract}
Multi legged robots are used in space studies, first aid, search and rescue activities in natural disasters, defense industry, detection and destruction of dangerous and explosive materials, mining, nuclear power stations and many other fields. A hexapod robot, which is in the classification of multi-legged robots, is defined as a robot with six legs to walk or move. There are so many possibilities for leg placement, leg designs and gait patterns in hexapod robots. It is preferred because it has the ability to move stable and flexible on any surface. In this paper, the hexapod robot was designed and manufactured with bluetooth control, and the strength analyzes of the body and leg linkage were carried out in the Ansys program.
\end{abstract}

Keywords: Bluetooth control, hexapod robot, strength analysis, servo motor.

\section{Bluetooth Kontrollü Hexapod Robot Tasarımı}

$\ddot{O} z$

Çok ayaklı robotlar uzay çalışmalarında, doğal afetlerde ilk yardım ile arama ve kurtarma faaliyetlerinde, savunma sanayisinde, tehlikeli ve patlayıcı maddelerin tespit ve imhasında, madencilikte, nükleer santrallerde ve daha birçok alanda kullanılmaktadırlar. Çok ayaklı robotlar sınıflandırmasında yer alan hexapod robot, yürümek veya hareket etmek için altı ayağı olan bir robot olarak tanımlanır. Hexapod robotlarda ayakların yerleşimi, ayak tasarımları ve yürüyüş biçimleri için çok fazla olasılık bulunmaktadır. Herhangi bir yüzeyde dengeli, kararlı ve esnek hareket etme yeteneğine sahip olduğu için tercih edilir. Bu çalışmada hexapod robotun bluetooth kontrollü olarak tasarımı ve imalatı yapılmış, gövde ve ayak uzvunun mukavemet analizleri Ansys programında gerçekleştirilmiştir.

Anahtar Kelimeler: Bluetooth control, hexapod robot, mukavemet analizi, servo motor.

\footnotetext{
${ }^{*}$ Corresponding Author: kkavlak@,ktun.edu.tr
} 


\section{Introduction}

Multi legged robots are used in space studies, first aid in natural disasters, search and rescue activities, defense industry, detection and destruction of hazardous and explosive materials, mining, nuclear power plants and many other fields. Multi-legged robots are named according to the number of legs. Two legged (biped), four legged (quadruped), six legged (hexapod), etc. The most important advantages of six-legged robots compared to others are their very high load carrying capacity and high stability and stable walking structure. There are many studies and publications on multi legged robots in the literature [1-9]. These studies increasingly continue on the robot's mechanism, motion planning, control methods, kinematic and dynamic analysis.

\section{Hexapod Robot}

Hexapod robot, which is included in the multi-legged robots classification, is defined as a robot that has six legs to walk or move. There are many possibilities for the placement of legs, leg designs and gait patterns in hexapod robots. The legs can be designed as three pieces symmetrically on each side of the body. In addition, the mobility of each leg can be increased by making a more complex design in the form of a circle. Much more designs can be created if animal inspiration is taken for rectangular designs. In these designs, there is faster movement in the forward direction and slow motion in the turns. Six legged robots have more gait variation than four legged robots. This is because three leg just touch the ground to keep the robot balanced. Since the number of leg in the six legged robot is higher than the four legged robot, the combination is greater for the number of leg in contact. The robot manufactured in this paper has a total of 18 degrees of freedom, with each leg having 3 degrees of freedom. This means being able to move 18 different joints in different positions. Legs are positioned symmetrically on both sides. Servo motors provide movement of joints. Servo motors that connect the legs to the body allow it to rotate sideways. The other two servo motors provide movement of the joints. Average walking speed of a person is $5 \mathrm{~km} / \mathrm{h}$. The hexapod robot was built to take $2.7 \mathrm{~cm}$ long steps in 1 second, taking into account the average human walking speed. The hexapod robot modeled in the Solidworks program is shown in Figure 1.

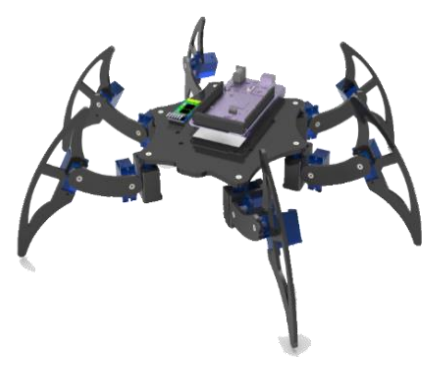

Figure 1. General view of the hexapod robot

\subsection{Hexapod Robot Walking Types}

Many different walking types have been developed for robots with six or more legs. Some of these methods are metachronal walking and tripod walking. The basic movement logic of tripod walking is that it goes in a zigzag pattern. In metachronal walking, it is a more determined step by providing slow movement. It is used for moving on rough terrain.

\subsubsection{Metachronal Walk Mode}

In this walking mode, the robot moves one leg at a time. It starts by lifting the moving leg first and slowly lowers it down until the leg touches the ground. Then the movement of the other legs begins. The sequence of movements is very slow in this walking mode. Gives a stable progression ability for the robot. Hexapod robot leg positions are given in Figure 2. Respectively, the R3-R2-R1-L1-L2-L3 legs move forward (Figure 3). The body is behind. The movement is provided by the legs pulling the body forward by stepping on the ground to move the body forward [10].

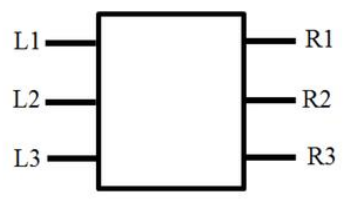

Figure 2. Hexapod robot leg positions

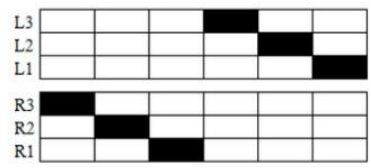

Figure 3. Leg movement sequence in metachronal walking mode

\subsubsection{Tripod Walk Mode}

In this walking mode, three legs hold the robot down on the ground. At the same time, the other three legs rise and take the specified step for walking speed. In order for the robot to progress, it must repeat a certain walking algorithm. First of all, the L1-R2L3 legs, which are named as the 1st group, move forward respectively. Later, the R1-L2-R3 legs, named as the 2nd group, move backwards respectively. Then, the 1 st group legs turn backwards, the 2nd group legs forward, and the movement is achieved (Figure 4) [11].

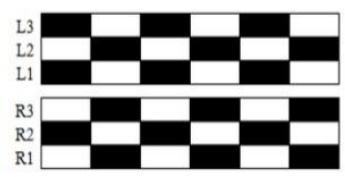

Figure 4. Leg movement sequence in tripod walking mode

\subsection{Parts Used in Hexapod Robot Manufacturing}

Arduino is a physical programming platform that consists of an Input/Output board and an implementation of the processing/wiring language in the development environment. The 
hardware of Arduino boards includes an Atmel AVR microcontroller (such as ATmega328, ATmega2560, ATmega32u4), programming and side elements required for connection to other circuits. Each Arduino board has at least one volt regulated IC and a $16 \mathrm{MHz}$ crystal oscillator (sometimes ceramic resonator). An external programmer is not needed for programming on Arduino boards, because a bootloader program is pre-written on the microcontroller on the board. The Arduino Mega2560 used in the hexapod robot is an Arduino board containing an Atmega2560 microcontroller. The Arduino Mega2560 can be connected to a computer, powered by an adapter or battery. It is the name of the short range radio frequency (RF) technology that eliminates the Bluetooth cable connection. Hc-05 bluetooth module is used in hexapod robot.

Nylon or polyamide is used as ABS material. It takes the form of filament by tightening the powders. It is a reliable material for three-dimensional printing. It is flexible and durable. Although its natural color is white, it can be colored before or after printing. ABS material can be damaged if exposed to intense sunlight. For this reason, it is a good solution to paint the part in products that will be under intense sunlight.

Servo is an automatic device that detects the operation of any mechanism and controls it with the help of a side feedback mechanism and removes the error. Servomotor is the most used motor type in robot technology. These systems can be used mechanically as well as electronically and hydraulicpneumatically. Servo motors are a mechanism in which parameters such as output, mechanical position, speed or acceleration are controlled. Servo motor has AC, DC or stepper motor.

It also includes the driver and control circuit. Small R/C servo mechanism parts are shown in Figure 5: 1. Electric motor, 2. Voltmeter, 3. Impeller, 4. Actuator arm. Micro Servo Motor 9G (Figure 6) used in the hexapod robot is small and light as well as high output power. It can rotate approximately $180^{\circ}\left(90^{\circ}\right.$ in each direction) and takes up less space than its standards. Hexapod robot leg and micro servo motor connection are given in Figure 7.

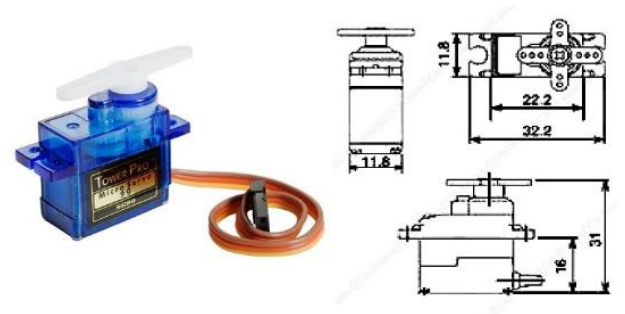

Figure 6. Micro servo motor 9G

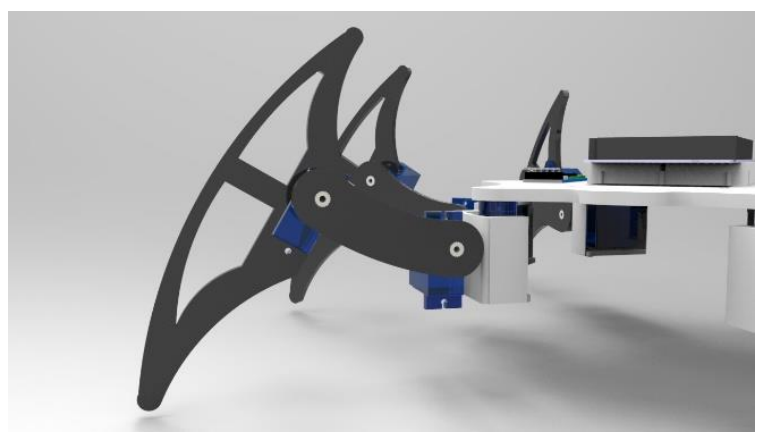

Figure 7. Hexapod robot leg and micro servo motor connection

\section{Strength Analysis}

The weight of the body and other electronic equipment must be light in order for the hexapod robot to perform its movement. Mechanical parts are made of ABS to reduce weight. It is assumed that the robot has a total weight of $0.5 \mathrm{~kg}$. In order to perform the analysis in the Ansys program, six motor holes in the body were fixed and a $5 \mathrm{~N}$ force was applied to the body surface area. The stress and deformation values of the robot's body and legs were analyzed and found. Accordingly, it is seen in Figure 8 that maximum stress occurs around the pin holes where the body and the leg meet. According to Figure 9, maximum deformation occurred around the center of the body. It is seen that the deformation decreases and is minimum as it moves away from the center. In Figure 10, it is seen that the maximum stress occurs around the pin holes where the leg link is connected. In Figure 11, the maximum deformation occurred at the tip of the leg link. It is seen that the deformation decreases and is minimum as it approaches the center.

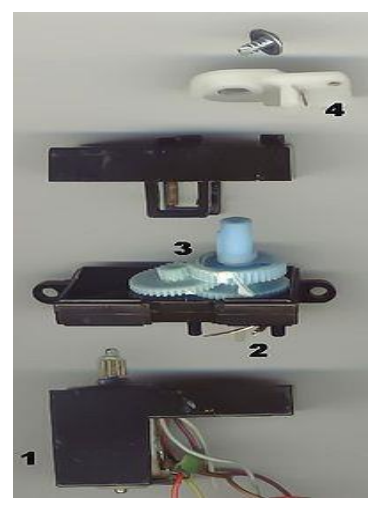

Figure 5. Small R/C servo mechanism parts

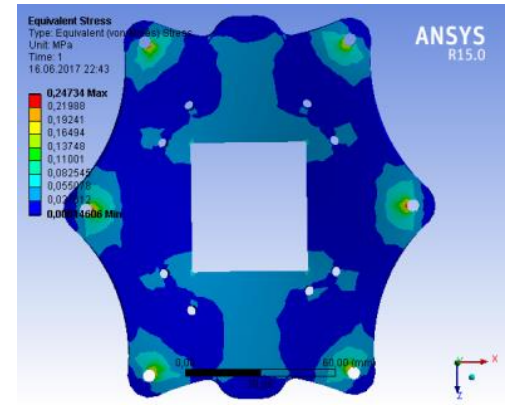

Figure 8. Von-Mises stress of the body 


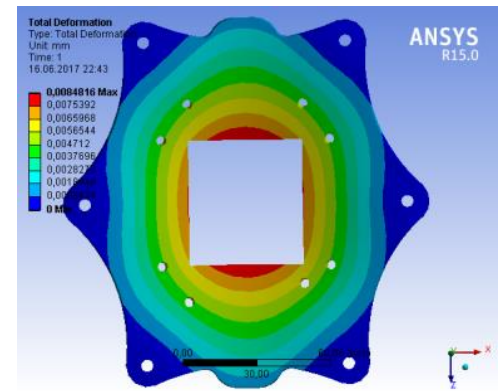

Figure 9. Total deformation of the body

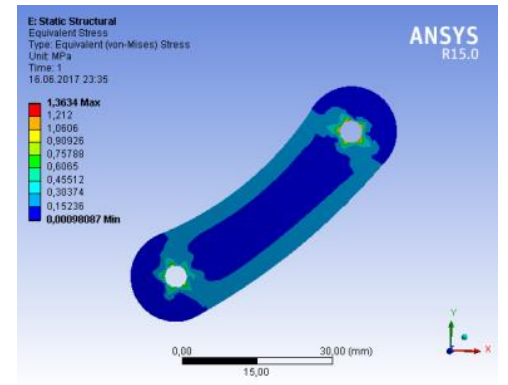

Figure 10. Von-Mises stress of the leg link

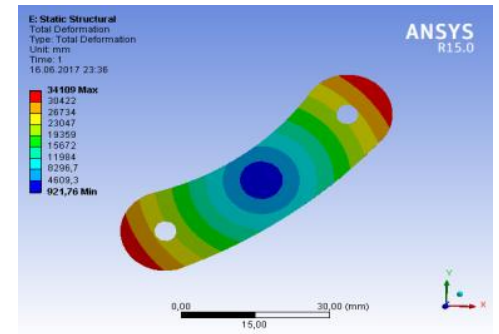

Figure 11. Total deformation of the leg link

\section{Conclusion}

The most important advantage of hexapod robots compared to two and four legged robots is that they move steadily. ABS material was chosen in robot manufacturing because of its light weight and strength. Two different walking modes, metachronal and tripod, were applied to the robot. After the legs moved forward in metachronal walking mode, the robot's movement was achieved by keeping the legs on the ground. However, it has been observed that the robot does not work as desired, and the body wobbles itself forward. For this reason, tripod walking mode is used for more efficient operation. As a result of the strength analysis, it was observed that the maximum stresses occurred around the center of the unloaded body and the pin holes where the leg part was connected.

\section{References}

[1] C. A. Klein, K. W. Olson and D. R. Pugh, "Use of force and attitude sensors for locomotion of a legged vehicle over irregular terrain", In International Journal of Robotics Research 2 (2), pp. 3-17,1983.

[2] T. MamKegh, A. Hindash and M. Al - Jabari, Hexapod robot design, model and control, German Jordanian University, Germany, 2011.
[3] M. S. Erden, Six - legged Walking Machine: The Robot EA308, Middle East Technical University, Ankara, Turkey, 2006.

[4] D. Chàvez-Clemente, Gait Optimization for Multi-legged Walking Robots, with Application to a Lunar Hexapod. Ph.D. Thesis, Stanford University, California, CA, USA, 2011.

[5] T. Bartholet and R. Crawson, Robot Applications for Nuclear Power Plant Maintenance; EPRI Report-NP-3941, Research Report Center: Palo Alto, CA, USA, 1985.

[6] M. Oku, H. Yang, G. Paio, Y. Harada, K. Adachi, R. Barai and K. Nonami, "Development of hydraulically actuated hexapod robot COMET-IV-The 1st report: System design and configuration", In Proceedings of the 2007 JSME Conference on Robotics and Mechatronics, Akita, Japan, 26-28 May 2007.

[7] M. Raibert, Legged Robots that Balance; MIT Press: Cambridge, London, pp. 180-201, 1986.

[8] J. Byrd and K. de Vries, "A six-legged telerobot for nuclear applications development”, Int. J. Robot. Res., 9, 43-52. 1990.

[9] F. Delcomyn and M. E. Nelson, Architectures for a biomimetic hexapod robot. Robot. Auton. Syst., 30, 5-15, 2000.

[10] G. Carbone and M. Ceccarelli, Legged robotic systems. In Cutting Edge Robotics, V. Kordic, A. Lazinica, M. Merdan, Eds., InTech: Vienna, Austria, pp. 553-576, 2005.

[11] K. K. Moncal ve Ö. C. Aydın, "Örümcek Robot Sistem Tasarımı ve Gerçekleşmesi”, 15. Otomatik Kontrol Ulusal Toplantıs1-TOK2013, İnönü Üniversitesi, 1344-1349, 26-28 Eylül 2013. 